\title{
Produksi Zat Antimikroba Melalui Reaksi Biginelli Menggunakan Katalis Passiflora Flavicarva
}

\author{
Aceng Saripudin ${ }^{1^{*}}$ dan Imam Darmawan ${ }^{2}$ \\ 1,2Program Studi Pendidikan Kimia Program Pascasarjana Universitas Negeri \\ Semarang, Indonesia
}

*Email: aceng.saripudin@yahoo.com

\begin{abstract}
Abstrak
Tujuan penelitian ini adalah untuk memproduksi zat antimikroba melalui reaksi siklokondensasi Biginelli menggunakan katalis larutan buah markisa (Passiflora Flavicarva). Zat antimikroba ini merupakan hasil reaksi siklokondensasi biginelli dari aldehid, etil asetoasetat, dan urea atau tiourea yang memiliki aktivitas biologis. Reaksi ini merupakan reaksi kondensasi antara benzaldehid 6, 2indanon 2 dan urea 7 dalam suasana asam Identifikasi senyawa dihidropirimidinon dilakukan dengan uji FT-IR dan uji GC-MS. Dari hasil penelitian zat antimikroba dengan katalis larutan buah markisa membuktikan bahwa larutan buah markisa belum dapat digunakan sebagai katalis memproduksi zat antimikroba melalui reaksi siklokondensasi Biginelli.
\end{abstract}

Kata kunci : antimikrob; markisa; passiflora flavicarva; biginelli; siklokondensasi

\section{Pendahuluan}

Setiap tahun, jutaan orang di seluruh dunia meninggal karena penyakit infeksi. Penyakit infeksi adalah penyakit yang disebabkan oleh virus, bakteri, parasit, dan jamur. Antimikroba merupakan obat yang mujarab dan penting untuk mengatasi infeksi. Antimikroba yang sering ditemui di pasaran seperti penisillin, tetrasikllin, dan streptomisin. Masing-masing antimikroba memiliki kerja yang berlainan terhadap suatu infeksi khusus.

Menurut Tanu, Penggunaan antimikroba terutama yang berspektrum luas dapat menimbulkan super infeksi, yakni suatu infeksi baru yang terjadi akibat terapi infeksi primer menggunakan antimikroba tertentu. Beberapa faktor yang memudahkan timbulnya super infeksi yaitu: (1) adanya faktor atau penyakit yang mengurangi daya tahan pasien, (2) penggunaan antimikroba yang terlalu lama, dan (3) luasnya spektrum aktivitas antimikroba obat, baik tunggal maupun kombinasi.

Adaptasi mikroorganisme terhadap antimikroba toksik juga tak terelakkan, sehingga resistensi terhadap zat penghambat pertumbuhan tersebar semakin luas dan dapat menjadi ancaman keberhasilan memberantas penyakit infeksi. 
Resistensi atau kepekaan sebenarnya bukanlah sifat yang mutlak tetapi bergantung pada konsentrasi antimikroba. Setiap organisme mempunyai batas konsentrasi antimikroba yang menunjukkan kepekaan mereka, di atas batas berarti peka dan di bawah batas berarti resisten.

Kappe (2000)b telah banyak melaporkan bahwa 3,4-dihidropirimidin-2(1H)-on dan turunannya yang memiliki kerangka dihidropirimidin dan berbagai macam aktivitas farmakologi dan terapetik. Senyawa dihidropirimidinon ini, memperlihatkan aktivitas sebagai antivirus, antihipertensi, antimikroba, dan anti inflamasi. Sebagian struktur tertentu ditemukan pada marin alkaloid yang mampu menghambat pengikatan HIV gp-120 ke sel CD4, yang sangat berguna dalam pengobatan AIDS. Semakin banyaknya penelitian bidang senyawa ini dan terutama sintesisnya, maka akan lebih banyak ditemukan senyawa-senyawa yang lebih poten dan mempunyai sifat-sifat yang lebih unggul dalam pengobatan.

Bose et al., (2005) mengembangkan metode sederhana, efisien dan lebih murah dalam sintesis 3,4-dihidropirimidin-2(1H)-on dengan menggunakan benziltrietilamonium klorida sebagai katalis pada kondisi bebas pelarut. Rameshwar et al., (2008) telah melakukan sintesis senyawa

3,4-dihiropirimidin-2-(1H)-on menggunakan etil asetoasetat atau metil asetoasetat, urea atau tiourea dan aldehid aromatik dengan $\mathrm{SnCl} 4$ pada kondisi bebas pelarut. SnCl4 adalah katalis asam lewis yang sangat kuat dan mempunyai kelarutan yang tinggi dalam pelarut organik maupun air. Waktu yang dibutuhkan untuk reaksi ini antara 30-90 menit dan menghasilkan rendemen sebesar 81-91\%.

sintesis Salehi et al., (2010) mengembangkan menggunakan katalis asam molibdophosphorik pada kondisi bebas pelarut di bawah penyinaran gelombang mikro (microwave). Sintesis dengan penyinaran gelombang mikro, memiliki keunggulan waktu reaksi yang lebih cepat dengan hasil rendemen yang lebih tinggi apabila dibandingkan dengan pemanas biasa atau dengan proses yang sederhana. Penggunaan katalis yang optimal pada reaksi ini sebesar 2\% H3PMo12040 menghasilkan rendemen sebanyak 79\% di bawah 32 penyinaran gelombang mikro (microwave) $600 \mathrm{~W}$ dan waktu radiasi 7 menit.

Baru-baru ini, Patil et al., (2011) juga mengembangkan sintesis 3,4-dihidropirimidin$2(1 \mathrm{H})$-on menggunakan jus nanas sebagai katalis alami. Sifat asam yang dimiliki jus nanas $(\mathrm{pH}=3,7)$ dapat digunakan sebagai katalis asam pengganti berbagai katalis asam homogen. Katalis asam dari jus nanas juga memiliki keunggulan yaitu bersifat lebih ramah lingkungan. Penelitian ini dilakukan pada suhu kamar dengan waktu 3,5 jam dan menghasilkan rendemen sebanyak 82\%.

Reaksi Biginelli adalah salah satu reaksi siklokondensasi multikomponen paling berguna. Reaksi siklokondensasi Biginelli pertama kali dilaporkan oleh Pietro Biginelli pada tahun 1893. Siklokondendasi Biginelli merupakan reaksi organik multikomponen yang menghasilkan senyawa 3,4-dihiropirimidin-2-(1H)-on dan derivat-derivatnya yang memiliki aktivitas biologis dan farmakologis. Reaksi siklokondensasi Biginelli merupakan sintesis satu reaktor (one-pot), sederhana dan multikomponen dari suatu senyawa antimikroba. Reaksi siklokondensasi Biginelli seringkali menghasilkan rendemen yang tidak memuaskan (20-60\%), kondisi reaksi yang keras, dan memerlukan waktu reaksi yang lama (Amini et al., 2006).

Beberapa tahun terakhir banyak metode yang dikembangkan dalam penelitian ini untuk memperbaiki dan mengembangkan hasilnya, misalnya adalah penggunaan katalis asam lewis dan asam protik di bawah refluks, kondisi bebas pelarut, dan menggunakan penyinaran gelombang mikro (Amini et al., 2006).

Zeolit adalah salah satu contoh katalis asam padat, dan dipilih sebagai katalis karena memiliki beberapa keunggulan seperti mudah dipisahkan dari produk karena tidak larut dalam media reaksi, secara termal lebih stabil pada suhu tinggi, dan memiliki ukuran pori yang besar sehingga dapat meningkatkan aktivitas katalitiknya.

Sintesis senyawa 3,4-dihiropirimidin-2(1H)-on melalui reaksi siklokondensasi Biginelli dari senyawa benzaldehid, urea dan etil asetoasetat menggunakan katalis zeolit tanpa pelarut disajikan pada reaksi berikut. 


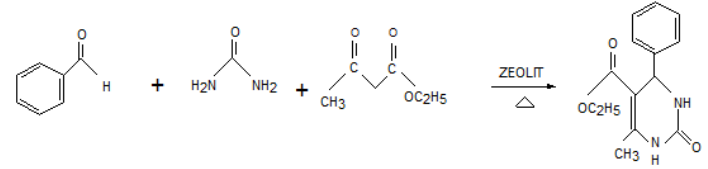

Reaksi Siklokondensasi Biginelli di atas berasal dari benzaldehid, urea dan etil asetoasetat dengan katalis zeolit dalam tanpa pelarut. Sedangkan mekanisme reaksi sintesis senyawa dihidropirimidinon ini disajikan pada reaksi berikut.

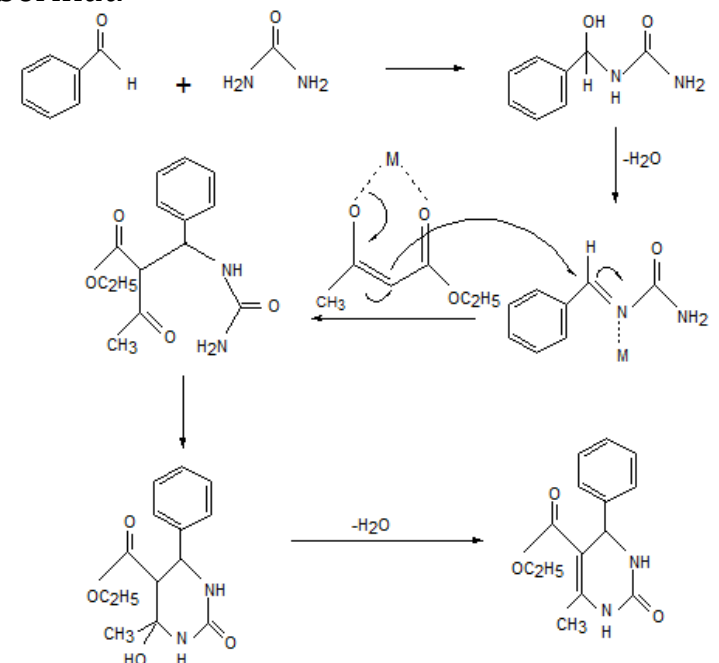

Berdasarkan mekanisme reaksi pembentukan senyawa dihidropirimidinon dapat diterangkan bahwa dengan adanya katalis asam akan memprotonasikan atom oksigen pada gugus karbonil benzaldehid yang selanjutnya akan mengaktivasi penyerangan pasangan elektron bebas dari arah atom nitrogen urea ke arah atom karbon pada gugus karbonil benzaldehid yang bersifat elektrofil membentuk intermediet ion iminium. Etil asetoasetat juga akan mengalami protonasi pada gugus karbonilnya dan berikatan dengan atom $\mathrm{H}$ pada zeolit sehingga terbentuk suatu enol, yang kemudian menyerang ion iminium. Penyerangan ion iminium oleh bentuk etil asetoasetat menghasilkan ureida rantai terbuka yang selanjutnya mengalami siklisasi dan melepas air membentuk produk 5-etoksikarbonil4-fenil-6-metil-3,4-dihidropirimidin-2(1H)-on.

Banyak modifikasi metode ini melibatkan pelarut-pelarut yang mahal, kondisi asam yang sangat kuat, waktu reaksi yang lama, temperatur reaksi yang tinggi, jumlah katalis yang stoikiometri, yang kemudian berdampak pada polusi lingkungan dan masih juga memberikan rendemen yang belum memuaskan.

Upaya penggunaan katalis heteropoliasam pada 3 dekade terakhir ini juga telah dilakukan. Katalis heteropoliasam telah menemukan sejumlah aplikasi sebagai katalis yang bermanfaat dan serbaguna. Katalis ini berupa padatan yang tak larut dalam pelarut-pelarut non polar tetapi sangat larut dalam pelarut polar. Katalis heteropoliasam memang memberikan sejumlah keuntungan, meliputi fleksibilitasnya yang tinggi dalam modifikasi kekuatan asam, mudah penanganannya, cocok bagi lingkungan, tidak beracun, dan kesederhanaan eksperimennya. Untuk praktikum yang dilakukan mencoba untuk menggunakan jus markisa sebagai katalisnya.

Buah yang memiliki rasa yang cukup asam ini memang cukup populer. Markisa (Passiflora quadrangularis L.) buah yang kaya akan vitamin B yang menenangkan, dan potassium yang merilekskan sistem syaraf ini konon biasa dikonsumsi Orang-orang Amerika Selatan secara tradisional untuk membantu tidur. Bahkan menurut mereka, makan 1 buah markisa sebelum tidur bisa membuat mimpi indah. Buah ini memang sangat banyak manfaatnya untuk kesehatan karena kandungan nutrisinya, buah markisa berkhasiat sebagai pereda nyeri, antikejang, kolitis, penenang, dan antiradang. Gangguan seperti sembelit, disentri, insomnia, gangguan haid, batuk, serak, tenggorokan kering juga bisa dihalau dengan buah ini. Daging buah markisa digunakan untuk merilekskan saraf saat sakit kepala, meredakan diare, dan neurastenia (kelelahan kronis, lemah, tidak nafsu makan, tidak bisa konsentrasi, dan susah tidur).

Penelitian invitro di University of Florida juga mendapati bahwa ekstrak buah markisa banyak mengandung fitokimia yang mampu membunuh sel kanker. Fitokimia tersebut antara lain polifenol dan karotenoid. Kandungan fitokimia yang lain dalam markisa adalah harman, harmol, harmalin, passaflorine, harmine, karotenoid, viteksin, krisin, dan isoviteksin. Sedangkan kandungan gizinya antara lain: energi, lemak, protein, serat, mineral, kalsium, fosfor, zat besi, karoten, tiamin, riboflavin, niasin, asam askorbat, dan asam sitrat. Kandungan asam yang terdapat pada buah markisa ini dapat digunakan sebagai 
katalis pada reaksi Biginelli untuk membuat zat antimikroba, dengan cara memanfaatkan jus buah markisa tersebut.

\section{Metode Penelitian}

Alat yang digunakan adalah labu erlenmeyer, gelas kimia, tabung kimia, labu ukur, pemanas listrik, termometer, timbangan analitik, blender, Spektrometer IR, dan Spektrometer GC.

Bahan yang digunakan adalah buah markisa mentah dan matang, benzaldehid, etil asetoasetat, dan urea.

Prosedur Kerja

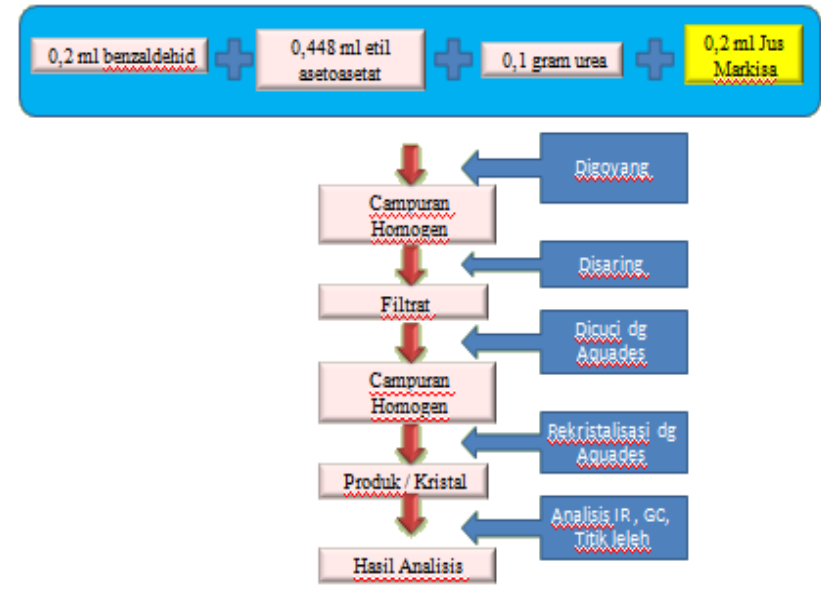

\section{Hasil Penelitian dan Pembahasan}

Prinsip dasar dari reaksi Biginelli dalam percobaan ini adalah mengikuti mekanisme reaksi kondensasi Aldol. Katalis yang digunakan pada reaksi Biginelli merupakan zat yang bersifat asam. Secara umum percobaan ini mengikuti mekanisme reaksi sebagai berikut.

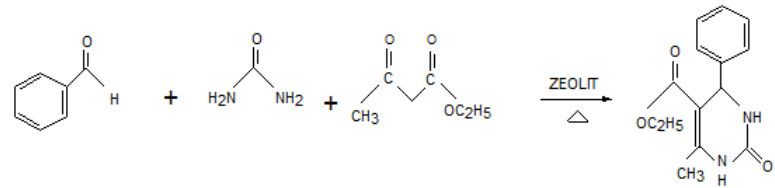

Dalam percobaan ini dengan katalis asam alami berupa jus markisa (Passiflora flavicarva), dengan variasi katalis menggunakan markisa yang mentah dan markisa yang matang untuk mengetahui keoptimalan dan rendemen yang dihasilkan dari reaksi Biginelli.
Pada saat awal perlakuan pada pencampuran pereaksi (benzaldehid, etil asetoasetat, etanol dan urea) dengan katalis (jus markisa), didapatkan campuran homogen yang mempunyai warna berbeda pada katalis markisa mentah dan matang. Pada katalis jus markisa matang menghasilkan campuran homogen berwarna bening, sedangkan yang mentah berwarna kuning seperti warna jus markisa awal. Kemudian setelah digoyang dan dipanaskan, terdapat produk berupa padatan meskipun hanya sedikit.

Setelah dilakukan penyaringan dan rekristalisasi menggunakan aquades, dihasilkan produk berupa kristal dengan massa menggunakan jus markisa mentah dan matang masing-masing 0,7582 gram dan 0,6507 gram. Sehingga jika besarnya rendemen yang didapatkan pada masing-masing katalis sebagai berikut.

Tabel 1. Perbandingan Rendemen Katalis Jus Markisa

\begin{tabular}{cccc}
\hline & & Massa & $\%$ \\
Katalis & Rendemen & Pereaksi & Rendemen \\
& (gr) & (gr) &
\end{tabular}

Jus

markisa $\quad 0,7582 \quad 1,357 \quad 56 \%$

mentah

\begin{tabular}{llll}
\hline Jus & & & \\
markisa & 0,6507 & 1,357 & $48 \%$ \\
matang & & &
\end{tabular}

Berdasarkan Tabel 1 di atas dapat dilihat bahwa rendemen (produk) yang dihasilkan lebih banyak yang menggunakan katalis markisa mentah dibandingkan katalis markisa matang. Hal ini dapat dikarenakan markisa mentah mempunyai kandungan asam yang lebih banyak dibandingkan markisa matang. Secara sederhana juga dapat diketahui bahwa markisa mentah mempunyai rasa yang lebih masam daripada markisa matang. Perbedaan jumlah rendemen 
yang dihasilkan dalam percobaan ini diakibatkan karena kandungan kadar asam pada katalis markisa yang matang dan yang mentah berbeda. Kadar asam cenderung lebih tinggi pada markisa yang masih mentah dibandingkan dengan markisa yang sudah matang. Secara faktual rasa markisa yang masih mentah jauh lebih masam dibandingkan dengan markisa yang sudah matang. Markisa yang sudah matang akan terasa lebih manis karena dimungkinkan semakin meningkatnya kadar glukosa pada markisa.Akan tetapi rendemen yang dihasilkan pada reaksi Biginelli dengan menggunakan katalis markisa relatif sedikit, dibandingkan dengan katalis lain yang pernah digunakan. Berdasarkan hasil penelitian dengan menggunakan katalis lain mampu menghasilkan rendemen sebesar 79 - 91 $\%$. Berarti buah markisa kurang optimal digunakan sebagai katalis pada reaksi Biginelli untuk menghasilkan zat antimikroba tersebut.

Kemudian untuk mengidentifikasi keberadaan senyawa hasil reaksi Biginelli dilakukan analisis menggunakan Spektrometer FTIR dan GC seperti Gambar 1a, Gambar 1b, Gambar 1c dan Gambar 1d.

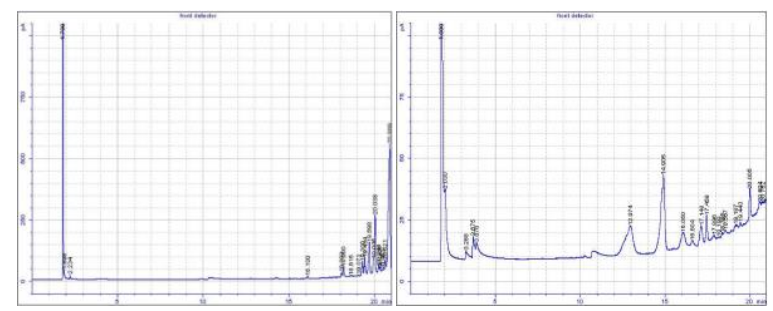

a

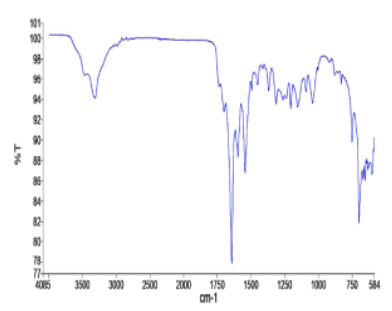

C b

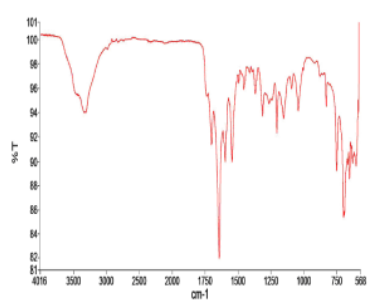

d
Gambar 1. (a) Hasil Analisis GC Sampel Halus; (b) Hasil Analisis GC Sampel Kasar; (c) Hasil Analisis FTIR Sampel Halus; (d) Hasil Analisis FTIR Sampel Kasar

\section{Simpulan}

Berdasarkan hasil praktikum produksi zat antimikroba melalui reaksi Biginelli dengan menggunakan katalis jus markisa yang diamati dapat diambil beberapa kesimpulan, sebagai berikut:

- Jus markisa kurang optimal untuk digunakan sebagai katalis reaksi Biginelli jika dibandingkan dengan katalis asam yang sudah pernah dilakukan. Hal ini terlihat besarnya rendemen yang dihasilkan hanya $48-56 \%$.

- Jus markisa mentah lebih efektif menghasilkan produk (kristal) zat antimikroba jika dibandingkan dengan jus markisa matang. Hal ini terlihat bahwa rendemen yang dihasilkan berupa kristal menggunakan jus markisa mentah dan matang masing-masing 0,7582 gram dan 0,6507 gram.

\section{DAFTAR PUSTAKA}

Amini, M. M., A. Shaabani and A. Bazgir. 2006. Tangstophoosporic Acid (H3PW12040): An efficient Eco-friendly Catalyst for the One-pot Synthesis of Dihydropyrimidin-2$(1 \mathrm{H})$-ones. Catalysis Communications 7: 843-847.

Bose, D.S., M. Sudharshan, and S. W. Chavhan. 2005. New Protocol for Biginelli ReactionA Practical Synthesis of Monastrol. Arkivoc iii: 228-236.

http://eemoo-esprit.blogspot.com/2010/11/nilaikandungan-gizi-markisa-passion.html. diunduh pada tanggal 4 Januari 2018.

http://jendelauntukkita.blogspot.com/2013/04/k andungan-nutrisi-dan-manfaatbuah 24.html. Diunduh pada tanggal 4 Januari 2018.

Kappe, C. O. 2000. Recent Advances in the Biginelli Dihydropyrimidine Synthesis New Tricks From an Old Dog. Acc. Chem. Res 33: 879.

Patil, S., S. D. Jadhav, and S. Y. Mane. 2011. Pinneapple Juice as a Natural Catalist: An Excellent Catalist for Biginelli Reaction. 
International Journal of Organic Chemistry. I: $125-131$.

Rameshwar, N., T. Parthasarathy., A. RamReddy. 2008. Tin (IV) catalized one-pot synthesis of 3,4-dihidropyrimidin-2(1H)-ones under solvent free conditions. Indian Journal Chemistry 47 B: 1871-1875.

Ritmaelani. 2006. Sintesis 4-fenil-3,4-tetrahidroindeno [2,1]-pyrimidin-2-on (LR-1). Majalah Farmasi Indonesia 17(3): 149-155.

Salehi, H., S. Kakaei., S.J. Ahmadi., M. A. F. Zareh., S.M. S. Kiai., H. R. Pakoyan and T. Ahmadi. 2010. Green procedure for synthesis of 3,4 dihidropirimininones using 12molybdophosporic acid, as a catalist and solvent free condition under microwave irradiation. Journal of Applied Chemical Researce Archive of SID 4 (14): 5-10.

Suwandi, Usman.1992. Resistensi Mikroba Terhadap Antibiotik. Jurnal Cermin Dunia Kedokteran 70.

Supartono. 2011. Memahami Antibiotika Bagi Kehidupan Manusia. Semarang: UNNES Press.

Tanu, Ian. 2009. Farmakologi dan Terapi Edisi 5. Jakarta: Universitas Indonesia. 